\title{
BRPKM
}

Buletin Riset Psikologi dan Kesehatan Mental

http://e-journal.unair.ac.id/index.php/BRPKM

e-ISSN: 2776-1851

ARTIKEL PENELITIAN

\section{Hubungan Beban Kerja dengan Stres Kerja Anggota TNI AD yang Bertugas di Wilayah Rawan Konflik}

\author{
NOVA ANDYA SARI \& NURUL HARTINI* \\ Fakultas Psikologi Universitas Airlangga
}

\begin{abstract}
ABSTRAK
Tujuan penelitian ini adalah untuk mengetahui hubungan antara beban kerja dengan stres kerja pada anggota TNI AD yang melaksanakan tugas di Papua. Penelitian ini menggunakan metode pendekatan kuantitatif dengan metode survei pada 83 orang anggota TNI AD yang sedang bertugas di Papua dalam kurun waktu minimal 3 bulan. Pengumpulan data menggunakan skala beban kerja untuk mengukur tingkat beban kerja dan skala stres kerja untuk mengukur tingkat stres kerja yang dialami oleh anggota TNI AD tersebut. Hasil analisis data dengan pearson dimana ditemukan hubungan antara beban kerja dengan stres kerja bersifat positif. Dikatakan bahwa semakin tinggi nilai beban kerja, maka semakin tinggi stres kerja yang dirasakan, begitupun sebaliknya.
\end{abstract}

Kata kunci: beban, papua, stres, TNI

\section{ABSTRACT}

The purpose of this study was to determine the relationship between workload and work stress on members of the Indonesian Army who carry out their duties in Papua. This study uses a quantitative approach with a survey method on 83 members of the TNI AD who are on duty in Papua for a minimum of 3 months. Data collection uses a workload scale to measure the level of workload and a work stress scale to measure the level of work stress experienced by members of the Indonesian Army. The results of data analysis with Pearson where found the relationship between workload and work stress is positive. It is said that the higher the workload value, the higher the perceived work stress, and vice versa.

Keywords: papua, stress, TNI, workload

Buletin Penelitian Psikologi dan Kesehatan Mental (BRPKM), 2021, Vol. 1(2), 1298-1305

*Alamat korespondensi: Fakultas Psikologi Universitas Airlangga, Kampus B Universitas Airlangga Jalan Airlangga 4-6 Surabaya 60286. Surel: nurul.hartini@psikologi.unair.ac.id

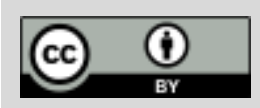

Naskah ini merupakan naskah dengan akses terbuka dibawah ketentuan the Creative Common Attribution License (CC-BY-4.0) (http://creativecommons.org/licenses/by/4.0), sehingga penggunaan, distribusi, reproduksi dalam media apapun atas artikel ini tidak dibatasi, selama sumber aslinya disitir dengan baik. 


\section{P E N D A H U L U A N}

Negara Kesatuan Republik Indonesia (NKRI) terdiri atas suku bangsa, budaya, luasnya tanah serta keberagaman yang begitu kaya di Indonesia. Banyaknya keberagaman di Indonesia diperlukan suatu lembaga yang harus melindungi serta menjaga kedaulatan dan keamanan bagi Indonesia sehingga terbentuklah TNI. Tugas pokok TNI adalah memelihara kedaulatan negara, melindungi keutuhan wilayah suatu negara. Salah satu tugas pokok TNI adalah dengan melaksanakan operasi-operasi militer untuk kepentingan perang dan pemeliharaan negara. Tugas atau perintah yang didapatkan para anggota TNI harus dilaksanakan meskipun konsekuensi yang didapatkan sangat berat. Apabila tugas atau perintah yang diberikan tidak dikerjakan secara baik dan benar, maka tak jarang mereka akan mendapatkan teguran bahkan hukuman fisik. Dengan kondisi seperti ini, tak jarang mereka merasa tertekan dan mudah mengalami stres. Tingginya tingkat stres anggota TNI tidak bisa dihindari ketika mereka mendapatkan tugas di wilayah perbatasan atau bagian negara rawan konflik yang memerlukan penangan khusus demi keamanan wilayah tersebut. Tingkat stres yang tinggi bisa menyebabkan dampak yang tidak baik bagi kesehatan mental atau psikologis para anggota. Salah satu wilayah Indonesia yang rawan terjadinya konflik adalah wilayah Indonesia bagian timur, lebih tepatnya di wilayah Papua.

Wilayah Papua memiliki berbagai keragaman dan keunikan baik dari segi budaya, suku maupun etnis, serta kondisi geografis. Adanya keragaman budaya dan kelompok etnis yang cukup besar serta pengaruh kesukuan yang sangat kuat, membuat gesekan sosial antara kondisi keberagaman norma dan nilai yang dimiliki wilayah Papua. Kondisi geografis di Papua yang terbuka ikut mempengaruhi dinamika gerakan separatis di Papua. Selain itu, wilayah perbatasan di Papua relatif rentan terhadap penyeberangan perbatasan ilegal, penyelundupan barang dan orang, pencurian sumber daya alam, penyelundupan miras dan narkoba, munculnya kelompok kriminal bersenjata dan Organisasi Papua Merdeka (OPM). Hal tersebut menuntut para prajurit TNI untuk selalu berhati-hati saat bertugas seperti melakukan patroli keamanan maupun pemeriksaan patok perbatasan. Klassen dan rekan-rekannya (2010) menemukan faktor-faktor lain dari stres kerja pada TNI AD melalui wawancara dengan seorang prajurit TNI AD, yaitu mereka harus siap mati jika dikirim di daerah rawan konflik seperti di Papua dan Poso, adanya keberadaan ikatan dinas yang ditentukan langsung oleh Panglima militer atau Komando militer, keberadaan peraturan tertulis termasuk sanksi di setiap peraturan yang telah ditetapkan, serta harus selalu siap terhadap peringatan jika terjadi keadaan yang tiba-tiba atau tidak terduga (Klassen dkk., 2010). Ada juga ketakutan dan kecemasan jika menjadi penanggung jawab di wilayah rawan konflik, seperti ketakutan menjadi korban dalam suatu perkumpulan yang memicu konflik.

Dalam bentrokan baru-baru ini di Papua, dua anggota Satgas Gakkum Polri dan polisi tewas dalam baku tembak dengan Kelompok Kriminal Bersenjata (KKB) Organisasi Papua Merdeka (OPM) di Distrik Sujapa, Kabupaten Intan Jaya, Papua, sekitar pukul 15.30 pada Selasa, 17 Desember 2019 (Koagouw, 2019). Selain itu, ada juga kasus penembakan di mana dua anggota staf medis gugus tugas khusus Covid19 Kabupaten Intan Jaya di Papua yang ditembak mati oleh KKB pada Jumat 22 Mei 2020. Pada hari kamis, tanggal 17 Desember 2020, telah terjadi kontak tembak antara Satgas Apter Koramil Hitadipa dengan KKSB di kampung Sugap Lama, Distrik Hitadipa Kab, Intan Jaya. Hal ini menyebabkan satu orang meninggal dunia dengan tembakan di lengan dan terkena dua tebasan parang di wajah. Lalu, pada tanggal 15 februari 2021 juga terjadi baku tembak di pos komando taktis pasukan raider di Kabupaten Intan Jaya, Papua. Hal ini menyebabkan satu anggota gugur karena mengalami luka tembak. Tercatat selama 2020, KKB melakukan 23 kasus penembakan, penganiayaan, dan perampasan senjata api yang menewaskan 10 warga sipil dan tiga tentara. 
Setiap orang pasti pernah mengalami stres dalam bekerja. Akibat stres, apa yang dilakukan seringkali tidak maksimal bahkan bisa pingsan. Pada dasarnya setiap orang akan mengalami stres terkait pekerjaan (Joshi \& Joshi, 2009). Stres kerja adalah respon penyesuaian individu karena perbedaan individu atau proses psikologis, proses ini adalah hasil dari setiap perilaku eksternal (lingkungan), situasi atau peristiwa yang memaksakan terlalu banyak persyaratan psikologis atau fisik pada seseorang (Haryanti dkk., 2013). Stres adalah keadaan internal yang disebabkan oleh tuntutan fisiologis pada tubuh, lingkungan, dan kondisi sosial yang dianggap berbahaya, tidak terkendali, dan di luar kemampuan koping pribadi (Lazarus \& Folkman dalam Biggs dkk., 2017). Suma'mur (1967) menyatakan bahwa kesehatan jiwa merupakan syarat mutlak untuk mencapai produktivitas yang tinggi, dan ketidakcocokan seseorang atau cacat mental dan fisik dapat menghalangi manusia untuk memperbaharui kemampuannya. Ini mungkin masalah kinerja seseorang di tempat kerja atau bahkan kegagalan. Ada dua sumber stres terkait pekerjaan, stres di luar pekerjaan (life stress) dan stres dari pekerjaan itu sendiri (job stress).

Safitri (2020) berpendapat bahwa beberapa faktor yang menimbulkan stres kerja yaitu seperti lingkungan fisik seperti ventilasi, penerangan, kebisingan serta karakteristik tugas. Sumber stres kerja yang dialami oleh karyawan antara lain adalah tuntutan tugas, tuntutan peran dan tuntutan pribadi. Respon individu terhadap stres mencakup perspektif perilaku, kognitif, fisik, dan psikologis. Respons perilaku termasuk peningkatan merokok dan minum, kehilangan nafsu makan, atau makan berlebihan. Dalam respon kognitif individu akan sulit berkonsentrasi, tidak mampu mengambil keputusan dan peka terhadap ancaman. Reaksi fisiologis berupa sulit tidur, sakit kepala, dan sulit buang air besar.

Pada saat yang sama, perasaan marah, cemas dan depresi muncul dalam respon psikologis (Handoyo, 2001). Stres prajurit TNI disebabkan oleh berbagai faktor, termasuk banyaknya pekerjaan yang mereka jalani. Munandar (2001) menyatakan bahwa banyaknya beban kerja secara fisik dan mental maka dapat mempengaruhi aktivitas serta pekerjaan tersebut, jika beban kerja lebih kecil maka dampak pada tekanan kerja juga akan sangat kecil (Munandar, 2001). Oleh sebab itu, para TNI memiliki beban kerja yang tinggi karena adanya beban tugas yang berat seperti menghadapi peperangan serta harus kuat dalam menghadapi kondisi yang ekstrim menyebabkan beban kerja pada TNI jauh lebih besar. Tidak hanya itu saja, beban kerja yang terlalu besar juga akan berdampak pada beban mental dan psikologis pada TNI (Munandar, 2001).

Munandar (2001) mengemukakan bahwa beban kerja merupakan kombinasi dari pekerjaan kuantitatif dan kualitatif. Beban kerja kuantitatif adalah ketika ada terlalu banyak atau terlalu sedikit tugas, sedangkan beban kerja kualitatif adalah ketika pekerja merasa tidak mampu melakukan tugas atau tidak menggunakan keterampilan atau potensi mereka. Beban kerja terlalu besar atau terlalu kecil pada pekerja dapat menyebabkan penyakit atau gangguan terkait pekerjaan. Beban kerja yang berlebihan atau rendah juga dapat menyebabkan stres kerja (Manuaba dalam Tarwaka \& Sudiajeng, 2000). Terdapat dua faktor yang berhubungan dengan beban kerja, yaitu faktor eksternal yang berasal dari tugas fisik dan mental, organisasi dan lingkungan kerja di luar tubuh pekerja (Manuaba dalam (Tarwaka \& Sudiajeng, 2000), 2000)). Faktor kedua adalah faktor internal, yang berasal dari dalam tubuh dan merupakan hasil respon terhadap beban kerja eksternal (seperti jenis kelamin, usia, motivasi, kepuasan, dll). Beban kerja di luar kapasitas pribadi akan menempatkan karyawan di bawah banyak tekanan. Sebaliknya, jika beban kerja dibebankan pada industri ringan, maka tingkat stres akan berkurang (Munandar, 2001).

Beban kerja dan stres kerja yang berlebih dapat menyebabkan benturan-benturan atau tekanantekanan yang terjadi pada diri yang dapat menimbulkan dampak negatif bagi pegawai. Hauck dan rekanrekannya (2008) menyatakan bahwa penumpukan beban kerja akan mengakibatkan penurunan pada 
kinerja dan meningkatkan stres kerja. Beban kerja yang berlebih dapat mengakibatkan produktivitas kerja individu menjadi menurun (Wijono, 2006). Dengan demikian, instansi harus terus berupaya memotivasi pegawai untuk dapat mengatasi tekanan-tekanan tersebut sehingga tidak menjadi masalah dalam internal perusahaan yang akan menghambat kinerja pegawai. Oleh karena itu, beban kerja yang diberikan kepada seorang pekerja sesuai dengan kemampuannya. Hal ini dikarenakan beban kerja sangat berpengaruh pada tingkat stres individu, terutama seseorang yang bekerja di bidang militer, khususnya TNI. Di mana prajurit TNI memiliki tanggung jawab sebagai ujung tombak pertahanan, menjaga kedaulatan negara, dan menjamin keselamatan bangsa dari setiap ancaman. Hal ini, membutuhkan beban kerja yang sesuai dengan kemampuannya untuk menjalankan semua tugasnya secara maksimal agar tidak terjadi stres kerja yang tinggi yang dapat mengakibatkan kinerja individu menurun.

Dari beberapa penelitian sebelumnya, dapat disimpulkan bahwa orang yang bekerja di sektor jasa dan mengayomi masyarakat seringkali rentan mengalami stres kerja. Stres kerja sering terjadi pada orangorang yang berpengalaman di bidang kemanusiaan dan pelayanan masyarakat, seperti perawat, pekerja sosial, guru, konsultan, dokter, dan militer (Nugrahini, 2014). Orang yang bekerja di industri jasa memiliki terlalu banyak tuntutan tugas. Tuntutan tugas yang harus diselesaikan karyawan dapat menimbulkan stres (Iskandar, 2017). Brealey (2002) percaya bahwa ketika beban yang diberikan pada seseorang terlalu banyak atau melebihi kemampuan mereka, mereka akan berada dibawah tekanan yang berlebihan.

Berdasarkan fakta diatas, diketahui bahwa salah satu penyebab stres kerja yaitu beban kerja (Hurrel dalam Munandar, 2001). Dengan adanya fenomena tersebut, peneliti tertarik untuk meneliti lebih lanjut mengenai beban kerja dan stres kerja pada TNI AD yang sedang bertugas di wilayah rawan konflik, yang dalam penelitian ini berfokus pada wilayah Papua.

\section{Desain Penelitian}

\section{E T O D E}

Pada penelitian ini, peneliti menggunakan pendekatan kuantitatif dengan prosedur pengambilan data secara survei serta menggunakan kuesioner sebagai alat dalam mengumpulkan data, guna mengetahui hubungan antara beban kerja terhadap stres kerja pada anggota TNI AD yang sedang melaksanakan tugas di Papua. Dalam studi kuantitatif survei yang dilakukan, penelitian ini dilakukan dengan menyebarkan kuesioner pada partisipan yang berisi alat ukur beban kerja yang telah diadaptasi peneliti dari penelitian sebelumnya, serta alat ukur stres kerja yang telah diadaptasi peneliti dari penelitian sebelumnya yang serupa. Data dari responden tersebut selanjutnya dianalisis menggunakan teknik analisis korelasi pearson.

\section{Partisipan}

Partisipan dalam penelitian ini adalah anggota TNI AD yang ditugaskan di Papua dengan kurun waktu minimal 3 bulan. Penentuan jumlah sampel partisipan dalam penelitian ini, yaitu menggunakan metode non-probability sampling karena populasi dalam penelitian ini yang tidak diketahui secara jelas jumlahnya dan dengan teknik purposive sampling agar peneliti dapat menentukan berapa jumlah partisipan sesuai dengan kriteria yang dapat mewakili apa yang akan diukur, sehingga data yang didapatkan akan lebih spesifik sesuai dengan fokus penelitian. Jumlah populasi yang tidak diketahui jumlah pastinya membuat peneliti menentukan jumlah besar sampel minimal menggunakan rumus yang memunculkan hasil minimal sampel sebesar 58 partisipan (Tabachnick dan Fidell dalam Pallant, 2015). Jumlah partisipan dalam penelitian ini sebesar 83 orang (45,1\% rentang usia 25-30 tahun) yang 
merupakan anggota TNI AD berjenis kelamin pria. Terkait dengan pangkat di dalam pekerjaannya, responden yang berpartisipasi dalam penelitian ini memiliki pangkat Serka sebanyak 5,5\% (N=5), pangkat Sertu sebanyak 15,4\% (N=14), pangkat Serda sebanyak 8,8\% (N=8), pangkat Praka sebanyak 5,5\% ( $=5)$, pangkat Pratu sebanyak 36,3\% ( $=33)$, dan pangkat Prada sebanyak 19,8\% (N=18). Apabila dilihat berdasarkan daerah penempatan tugas, responden yang berpartisipasi dalam penelitian ini yang bertugas di Merauke sebanyak 12,1\% $(\mathrm{N}=11)$, bertugas di Puncak Jaya sebanyak 6,6\% $(\mathrm{N}=6)$, bertugas di Nabire sebanyak 8,8\% (N=8), bertugas di Ilaga sebanyak 12,1\% ( $\mathrm{N}=11)$, bertugas di Pos Caruk Se sebanyak 12,1\% (N=11), bertugas di Timika sebanyak 7,7\% ( $\mathrm{N}=7)$, bertugas di Nduga sebanyak 9,9\% (N=9), dan bertugas di Jayapura sebanyak 22\% $(\mathrm{N}=20)$. Partisipan tersebut diberikan informed consent terlebih dahulu sebelum melakukan pengisian kuesioner sebagai bentuk persetujuan partisipan dalam mengikuti penelitian ini.

\section{Pengukuran}

Pada penelitian ini, pengumpulan data dilakukan menggunakan skala beban kerja yang diadaptasi oleh peneliti dari penelitian sebelumnya yang disusun berdasarkan dimensi yang berkaitan dengan beban kerja yang terdiri dari 17 item dan disajikan berupa skala likert dengan 4 pilihan jawaban (1="sangat tidak sesuai", 4="sangat sesuai") (Manuaba dalam Tarwaka \& Sudiajeng, 2000), 2000). Selain itu, juga menggunakan alat ukur stres kerja yang diadaptasi oleh peneliti dari penelitian sebelumnya yang disusun berdasarkan dimensi yang dapat mempengaruhi stres kerja menurut yang terdiri dari 18 item dan disajikan dengan 4 pilihan jawaban (1="sangat tidak sesuai", 4="sangat sesuai") yang berupa skala likert (Cooper dalam Munandar, 2001).

\section{Analisis Data}

Pada penelitian ini, analisis data dilakukan dengan menggunakan teknik analisis korelasi pearson dengan bantuan aplikasi IBM SPSS Statistics 22 for Windows.

\section{HAS I L P EN EL I T I A N}

\section{Uji Deskriptif}

Uji deskriptif penelitian ini terdapat partisipan sebanyak 83 orang dengan nilai terendah pada variabel beban kerja sebesar 17 dan variabel stres kerja sebesar 18 sedangkan nilai tertinggi pada variabel beban kerja sebesar 68 dan variabel stres kerja sebesar 72. Nilai mean variabel beban kerja sebesar 42,5 sedangkan untuk variabel stres kerja sebesar 45. Berdasarkan norma kategorisasi, sebagian besar partisipan penelitian memiliki tingkat beban kerja yang sedang, yaitu sebesar $50,6 \%(\mathrm{~N}=42)$, serta memiliki tingkat stres kerja yang sedang, sebesar $67,5 \%(\mathrm{~N}=56)$.

\section{Uji Hipotesis}

Setelah dilakukan uji asumsi dan uji asumsi dapat terpenuhi, maka peneliti melakukan uji hipotesis yaitu uji korelasi yang dilakukan untuk mengetahui arah dan kekuatan hubungan linear dari kedua variabel. Uji korelasi dilakukan menggunakan teknik analisis korelasi pearson. Data yang diperoleh dalam penelitian ini menunjukkan $(r(83)=0,567 ; 95 \%$; $>0,000)$ sehingga diketahui bahwa terdapat hubungan yang signifikan antara variabel beban kerja dan variabel stres kerja. Kedua variabel dalam penelitian ini menunjukkan nilai korelasi yang positif dengan arti bahwa hubungan kedua variabel yang searah sehingga semakin tinggi nilai beban kerja yang dirasakan, maka semakin tinggi pula nilai stres kerja yang dirasakan, dan berlaku pula sebaliknya. 


\section{I S K U S I}

Berdasarkan hasil dari analisis korelasi pearson yang melihat hubungan beban kerja terhadap stres kerja pada anggota TNI AD yang bertugas di daerah rawan konflik yaitu Papua, didapatkan hasil bahwa beban kerja memiliki hubungan yang signifikan terhadap tingkat stres pada anggota TNI AD yang bertugas di Papua ( $p=0,000 ; r=-0,567)$. Hauck dan rekan-rekanya (2008) mengatakan bahwa adanya beban kerja dan tekanan kerja yang berlebihan akan memberikan dampak negatif pada TNI AD, salah satunya adalah menurunnya kinerja serta mengalami beban mental dan psikologis. Ini sesuai dengan penelitian yang menyatakan bahwa akibat beban kerja yang bertambah maka dapat mengalami penurunan produktivitas dalam bekerja (Wijono, 2006).

Hasil dari penelitian ini ternyata sejalan dan didukung oleh hasil dari penelitian sebelumnya. Haryanti dan rekannya (2013) menyatakan bahwa hubungan antara beban kerja dan stres kerja memiliki hubungan dalam kategori kuat serta arah hubungannya yang positif, maka dapat disimpulkan bahwa semakin meningkat beban kerja maka akan menyebabkan tingginya stres kerja. Puspitaninrum (2019) menunjukan hasil penelitian adanya hubungan positif yang signifikan antara beban kerja dengan stres kerja pada anggota polisi di Polrestabes Semarang dan berdasarkan hasil uji analisis korelasi parsial yang dilakukan penelitian ini menunjukkan bahwa beban kerja berkaitan dengan tekanan kerja, dan aspek-aspek yang mempengaruhi penelitian ini meliputi tugas, waktu, dan kondisi atau kondisi normal.

Dapat disimpulkan dari beberapa penelitian sebelumnya bahwa orang yang bekerja di industri jasa dan mengayomi masyarakat seringkali rentan terhadap stres. Hal ini didukung oleh penelitian yang menunjukkan bahwa stres kerja sering terjadi pada orang dengan latar belakang kemanusiaan dan pelayanan terkait masyarakat, seperti perawat, pekerja sosial, guru, konselor, dokter, dan tentara (Cooper dalam Nugrahini, 2014). Orang yang bekerja di industri jasa memiliki terlalu banyak tugas. Tuntutan tugas yang harus diselesaikan pegawai menjadi penyebab terjadinya stres (Iskandar, 2017).

\section{S I M P U L A N}

Penelitian ini berfokus mengenai hubungan beban kerja dengan stres kerja pada anggota TNI AD yang sedang bertugas di wilayah rawan konflik, dalam hal ini adalah daerah Papua. Berdasarkan hasil analisis data penelitian yang telah dilakukan, bahwa beban kerja memiliki pengaruh yang signifikan terhadap stres kerja pada anggota TNI AD yang ditugaskan di Papua. Hasil korelasi yang bersifat positif antara beban kerja dengan stres kerja sehingga dapat diartikan bahwa semakin tinggi beban kerja yang dirasakan, maka semakin tinggi pula stres kerja yang dirasakan, dan begitu pula sebaliknya.

Penelitian ini diharapkan dapat memberikan manfaat bagi penelitian selanjutnya dan juga bagi anggota TNI AD yang melaksanakan tugas di wilayah rawan konflik serta bagi komandan setiap jajaran. Dari hasil penelitian ini, peneliti menyarankan untuk penelitian selanjutnya dapat lebih memperhatikan pengawasan dan pendampingan dari berbagai aspek seperti proses pengisian skala, diharapkan selain beban kerja, serta faktor lain yang dapat menyebabkan stres kerja juga diperhatikan.

Berdasarkan hasil penelitian ini, peneliti memberikan rekomendasi kepada anggota TNI AD yang menjalankan tugas di daerah rawan konflik untuk tetap berpikiran positif terhadap beban kerja dan lebih memperlakukannya sebagai kewajiban yang harus dipenuhi. Memiliki fleksibilitas, loyalitas terhadap organisasi, dan menjaga profesionalisme sebagai anggota yang baik adalah kunci untuk menghindari hambatan psikologis di tempat kerja. Untuk komandan setiap lini, peneliti menyarankan untuk selalu memantau anggota melalui evaluasi, penelitian dan penyelidikan, atau partisipasi langsung 
untuk lebih dekat dengan anggota untuk menghindari kesenjangan antara komandan dan anggotanya dalam bekerja.

\section{U C A P A N T E R I MAKAS I H}

Dengan hormat, diucapkan terima kasih kepada Prof. Dr. Nurul Hartini, S.Psi, M.Kes., Psikolog selaku dosen pembimbing skripsi, Haryono dan Sunarsih selaku kedua orang tua penulis, seluruh saudara dan keluarga besar penulis, serta seluruh sahabat terdekat yang tidak dapat disebutkan satu persatu.

\section{DEKLARASI POTENSI TERJADINYA KONFLIK KEPENTINGAN}

Nova Andya Sari dan Nurul Hartini tidak bekerja, menjadi konsultan, memiliki saham, atau menerima dana dari perusahaan atau organisasi manapun yang mungkin akan mengambil untung dari diterbitkannya naskah ini.

\section{P UST AKA ACUAN}

Biggs, A., Brough, P., \& Drummond, S. (2017). Lazarus and Folkman's Psychological Stress and Coping Theory. The Handbook of Stress and Health, 349-364. https://doi.org/10.1002/9781118993811.ch21

Brealey, E. (2002). Seri 10 Menit Menghilangkan Stres. Batam: Karisma publishing group.

Handoyo, S. (2001). Stres Pada Masyarakat Surabaya. Jurnal Insan Media Psikologi, 3(12), 61-74.

Haryanti, H., Aini, F., \& Purwaningsih, P. (2013). Hubungan Antara Beban Kerja Dengan Stres Kerja Perawat Di Instalasi Gawat Darurat Rsud Kabupaten Semarang. Jurnal Manajemen Keperawatan, 1(1), 111590.

Hauck, E. L., Snyder, L. A., \& Cox-Fuenzalida, L. E. (2008). Workload variability and social support: Effects on stress and performance. Current Psychology, 27(2), 112-125. https://doi.org/10.1007/s12144008-9026-x

Iskandar. (2017). HUBUNGAN ANTARA BEBAN KERJA DENGAN STRES KERJA PRAJURIT YONIF 403/WP (Vol. 1, Issue 1).

Joshi, D., \& Joshi, M. (2009). Organizational Behavior. In Hospital Administration. Jaypee Brothers Medical Publishers. https://doi.org/10.5005/jp/books/10358_23

Klassen, R. M., Usher, E. L., \& Bong, M. (2010). Teachers' collective efficacy, job satisfaction, and job stress in cross-cultural context. Journal of Experimental Education, 78(4), 464-486. https://doi.org/10.1080/00220970903292975

Koagouw, M. O. (2019). Kronologis Dua Prajurit TNI Gugur Ditembak KKB Papua - Peristiwa. 18 Des 2019. Munandar, A. S. (2001). Psikologi Industri dan Organisasi. UI-Press.

Nugrahini, L. (2014). HUBUNGAN ANTARA BEBAN KERJA DENGAN STRES KERJA PADA ANGGOTA POLISI DI POLRESTA SURAKARTA. Universitas Muhammadiyah Surakarta, 1(1), 634. 
Pallant, J. (2015). SPSS Survival Manual: A Step By Step Guide to Data Analysis Using IBM SPSS. The McGraw-Hill Companies.

Puspitaninrum, S. (2019). HUBUNGAN ANTARA BEBAN KERJA DENGAN STRES KERJA PADA ANGGOTA POLISI DI POLRESTABES SEMARANG. In UNIVERSITAS ISLAM SULTAN AGUNG (Vol. 6, Issue 3).

Safitri, H. U. (2020). Hubungan beban kerja dengan stres kerja. Psikoborneo, 8(2), 174-179.

Suma'mur, P. (1967). Ilmu hygiene perusahaan dan kesehatan kerdja Book. Gunung Agung.

Tarwaka, S., \& Sudiajeng, L. (2000). Ergonomi untuk Keselamatan, Kesehatan Kerja dan Produktivitas.

Wijono, S. (2006). Pengaruh Kepribadian Type A dan Peran Terhadap Stres Kerja Manajer Madya. Jurnal INSAN, 8(3), 188-197. 